\title{
Identity in Online Personal Ads: A Multimodal Investigation
}

\author{
Kesumawati A. Bakar ${ }^{1}$ \\ ${ }^{1}$ School of Language Studies and Linguistics, Universiti Kebangsaan Malaysia, Malaysia \\ Correspondence: School of Language Studies and Linguistics, Universiti Kebangsaan Malaysia, Bangi, 43600, \\ Selangor, Malaysia. Tel: 60-12-775-5673. E-mail: kesuma@ukm.edu.my
}

\author{
Received: February 16, 2015 Accepted: March 13, 2015 Online Published: May 15, 2015 \\ doi:10.5539/ass.v11n15p313 \\ URL: http://dx.doi.org/10.5539/ass.v11n15p313
}

\begin{abstract}
A personal advertisement constitutes a distinct form related to the small ad family of genres. While small ads traditionally offer an object or a service, the personal ad offers but, most essentially, seeks a romantic partner. To date, studies of personal ads have mainly focused on patterns of represented traits in relation to identity, gender, age and sexuality in the verbal text. Given the self-promotional nature of the genre, image is also a powerful tool used as one of the resources for representing identity and engaging with others. Using social semiotic perspective and the framework of systemic functional linguistics, this study focuses on how identity is verbally and visually realised in online personal ads. This paper has two aims: the first is to show how resources from verbal and visual systems combine and complement one another to construe a variety of personal and social traits, clustering into different identity types. The second is to indicate the usefulness of these descriptions in facilitating a multimodal approach to the analysis of identity. The results revealed a convergence of verbal and visual resources in identity performances, construing the slim and attractive woman and the funny but sensitive guy, both aimed at invoking interest from potential partners. Identities emerged through the use of nominal groups and processes and the categorizations associated with these resources. Images that are displayed on the profile pages contain features that correspond to the tendered traits in the verbal description creating a holistic performance of online identities.
\end{abstract}

Keywords: multimodality, systemic functional linguistics, personal ads, identity, gender

\section{Introduction}

\subsection{Personal Advertisement}

The increasing popularity of personal advertisement (henceforth personal ad) among relationship-seeking adults has triggered studies in fields ranging from social sciences to humanities to computer sciences (e.g. Coupland, 1996; Baker, 2003; Elison et al., 2006). Findings have developed insights into various issues pertaining to social and cultural practices, ranging from language to gender to power relations in society. Social science researchers have for example been using personal ads to study what people are willing to disclose about themselves and what they are seeking in others for over thirty years. Some of the earliest findings of these studies (e.g. Cameron et al., 1977) have showed that people tend to make requests that are congruent with their sex-role stereotypes. For instance, women are more likely to express interest in financial security, sensitivity, and sense of humour of a prospective partner, while men are more likely to seek an attractive partner with whom they can have a sexual relationship. In cases where personal ads are used to measure the supposed desirability of certain attributes, findings have generally revealed that physical characteristics are generally more important than personality characteristics for men than women (e.g. Hogben \& Coupland, 2000; Miller et al., 2000; Bartholome et al., 2007).

A personal advertisement constitutes a distinct generic form, which is related to the small ad family of genres. While small ads traditionally offer a thing (e.g. a car) or a service (e.g. plumbing), the personal ad 'offers but, most essentially, seeks' (Shalom, 1997) a romantic partner. Accordingly, a personal ad is used for the purpose of 'selling' oneself and of 'seeking' a desired other for short and long term relationships (Shalom, 1997; Marley, 2000; Gibbs et al., 2006). Each construed identity in a personal ad is an offer that is intended to be exchanged for what is sought by others in the dating scene. The self becomes a commodified entity and advertisers compete for the time and effort of other members to read and respond to their profiles. With these aims in mind, advertisers are pushed into crafting a description that will positively highlight their identity in ways that they believe will 
help them achieve these objectives. Verbal and visual self-presentations thus become the tools of persuasion, manipulated to incite a response from potential partners.

Personal ad is an ideal site for examining the construction of identities. Salient preferences emerge in the selection of traits and the associated identity categories (e.g. physical attributes, behavioural traits and interests) and accordingly, these advertisements provide insights into advertisers' idealizations of self-identities and the behaviour of people seeking relationships in different societies and cultures (e.g. Coupland, 1996; Baker, 2003; Gama e Silva, 2007). While the written text presents the main means for representing the advertiser's identity, several researchers have discussed the benefits of attaching photos in online profiles (Walther, 2001; Fiore, 2002). Findings demonstrated that profiles with photos attracted a higher number of responses than those without. One significant factor here is the fact that physical attractiveness appears to be one of the most important characteristics men seek in their prospective partner (Bolig et al., 1984; Shalom, 1998). Accordingly, images function to validate the attractiveness of the advertisers (Jones, 2009, p. 117). Apart from functioning as one of the tools by which advertisers engender interest, images also reveal physiological (e.g. body type and facial features) and social information (e.g. occupation and interests) about the advertiser and thus are, to a certain extent, a manifestation of the written description.

Despite the vast number of studies that have been carried out on personal ads, identity in online personal ads have rarely been investigated as a construction of both verbal and visual performances. Attention has mostly been focused on patterns of represented traits in relation to identity, gender, age, sexuality and ethnicity either in written text (e.g. Jones, 2000; Baker, 2003; Bahiyah \& Kesumawati, 2011) or in images (Gallant et al., 2011). I will argue in this paper that construction of identity is a combination of both verbal and visual performances.

\subsection{Theories of Identity}

Conceptualizations of identity have evolved considerably over time. It is a notion whose conception and complexity has long been the subject of debate among essentialist and post-structuralist theorists. In the eighteen century of the Enlightenment era, the individual was understood as a self-sufficient person motivated by a combination of rational thoughts, experience and knowledge. Romantic expressivism came into the picture in the first half of the nineteenth century and re-theorised the individual as an entity that is driven by morality, sensibility and emotion (Benwell \& Stokoe, 2006, p. 19). At the end of twentieth century, identity has been reconceptualized as a socialized self as a result of 'crossing over' geographical boundaries and the exchange of experiences on the cyberspace. The socialized self in the modern era identifies with others by behaving, talking and emoting in similar manners, producing a homogeneity that is termed 'social identity' (Tajfel \& Turner, 1986) or 'collective identity' (Benwell \& Stokoe, 2006). At the same time however, individuals are also committed to distinguishing themselves from others, as a way of saying I am different from you in some ways, emotionally, morally, mentally and so forth (Woodward, 2004). Over the centuries, different ideologies and approaches in the conceptualization of identity have resulted in theories that are characterized by dichotomies - the internal vs. the external, the personal vs. the social and the essential vs. the dynamic. Despite this, the current consensus in contemporary identity research appears to be that these dichotomies are not irreconcilable. The poststructuralist turn in identity theorization proposed an alternative understanding of identity as a discursive performance (e.g. Butler, 1996), namely that identity is brought about discursively and interactively, rather than constituting a preexisting repertoire of traits. The emphasis is now on the emergent, performative aspect of identity construal. Discursive performance refers not only to the language that we use, but also other means of expressing ourselves, for example through attire, gesture, facial expression, music and so on. The approach to studying identity in this research is based on this premise - that identity comes into being by virtue of our performance, both verbally and visually.

\subsection{Linguistic Performance of Identities in Personal Ads}

A densely packed description of the identity forms one distinctive feature of a personal ad, brought about by word and spatial constraints imposed in both written and online personals. Identity description is characterized by strings of adjectives and nouns (Bruthiaux 1994) as illustrated by the two examples taken from my data.

I am a single lady, sensual, cool, attractive, romantic and a good looking girl...I am a friendly, understandable and straight forward person, but sometimes I am pretty talkative, stubborn and hot temper.

Coupland (1996) examined nouns and adjectives realizing attributes classifying gender (e.g. female, widower), age (e.g. 33 going on 13), appearance (e.g. tall, attractive), interests (e.g. music, cinema), career (e.g. company director) and a few others in her data and found enactments of identity that 'are grounded in cultural stereotypes about youth, femininity, masculinity, attractiveness, etc' (1996: 194). Shalom (1997) found that, regardless of gender and sexuality, hegemonic gendered discourses are enacted and perpetuated in a variety of ways: physical 
appearance is popularly sought by the men while career/solvency and capacity is sought by the women. Two things are pertinent from the above studies: that attributes are realized through nouns and adjectives - termed as the nominal group in SFG - and that the frequency and patterns of these items construe different types of identities and reveal gendered preferences in mate selection. Accordingly, nominal groups in personal ads provide one point of departure for the investigation of gender representations.

The use of $I$ is also significant in my data as it forms the second most frequently used word by men and women in their description e.g. I love the outdoors, I travel extensively. Its initial position in a clause gives thematic prominence to the writer and evokes a sense of proximity between the advertiser and the readers. Based on its high frequency, I-statement forms the second point of departure in the analysis of gender identities in my set of data.

\subsection{Identity Categorization in Personal Ads}

As this research is concerned with identity representations, two discourse-analytical concepts from social actor analytical framework (van Leeuwen, 2008) are utilized in the semantic sub-classifications of I-statement and nominal group. These social actor concepts are termed 'functionalisation' and 'identification'. Van Leeuwen (2008) argues that such concepts can help us 'investigate the words and expressions by users of language for answering the questions Who are you? (Who are we? Who is she/he? Who are they?)'.

Functionalisation occurs when people are defined in terms of an activity, in terms of something they do, for instance an occupation or role (van Leeuwen, 2008, p. 42). Besides occupational roles, my data show a further subset of roles and activities that relate to leisure. Leisure roles (e.g. a pianist and violinist) and activities (e.g. I can salsa a little) are particularly prominent in my data, and these features will be my addition to van Leeuwen's functionalisation category. Identification occurs when people are defined not in terms of what they do but in terms of what they, more or less permanently or unavoidably, are (van Leeuwen, 2008, p. 42). There are three types of identification: classification, relational identification and physical identification. Classification refers to major categories such as age, gender, provenance, class, wealth, race, ethnicity, religion, sexual orientation and so on. Relational identification is identification by means of personal, kinship or work relations with others and is realized by a closed set of nouns denoting such relations such as: friend, parents, brother, sister, colleague etc. Physical identification represents people in terms of physical characteristics, realized by pre-modified nouns such as long hair, fair complexion, or by adjectives such as tall, muscular, healthy and fit and attractive or by prepositional phrases with with or without, for example I am tall, with a slim figure and long black colour hair.

\section{Methodology}

\subsection{Multimodal Representation of Identity in Personal Ads}

Halliday \& Matthiessen (2004), Van Leeuwen (2008), Kress \& Van Leeuwen (2006), Painter \& Martin (2009), Mehrabian $(1971,1981)$ provided descriptions of both linguistic and visual semiotic systems for analysing multimodal complementarity in data ranging from picture books to body language. My work on multimodal representation has been influenced both by the nature of my data - personal advertisements - and the goal of providing an analytical framework that may be useful in analysing identity construction. With this in mind and given the available linguistic and visual descriptions of meaning-making systems, the resources are presented as sets of meaning-making potential with specific realisations, as shown in Table 1 below.

Table 1. Complementary meaning systems across image and language (adapted from Painter \& Martin, 2013)

\begin{tabular}{|c|c|c|c|}
\hline $\begin{array}{c}\text { VERBAL } \\
\text { meaning potential }\end{array}$ & realisation & $\begin{array}{c}\text { VISUAL } \\
\text { meaning potential }\end{array}$ & realisation \\
\hline $\begin{array}{l}\text { Processes (actions) and } \\
\text { participant/s }\end{array}$ & $\begin{array}{l}\text { I-statement; material, } \\
\text { behavioural, verbal, } \\
\text { mental processes } \\
\text { e.g. I go to the gym often. }\end{array}$ & $\begin{array}{l}\text { Visual processes } \\
\text { action } \\
\text { perception } \\
\text { cognition } \\
\text { talking } \\
\end{array}$ & $\begin{array}{c}\text { Depicted action with: vectors, } \\
\text { gaze vectors, } \\
\text { face/hand gestures }\end{array}$ \\
\hline $\begin{array}{l}\text { Participant gender, ethnicity, } \\
\text { physical traits, personal traits, } \\
\text { occupational roles, leisure roles. }\end{array}$ & $\begin{array}{l}\text { I-statement, nominal } \\
\text { group structures; } \\
\text { functionalisation \& } \\
\text { identification. } \\
\text { e.g. I am slim with brown } \\
\text { hair. }\end{array}$ & Participant depiction & $\begin{array}{c}\text { Depicted qualities and } \\
\text { attributes e.g. body type, } \\
\text { attire etc. } \\
\text { Body language i.e. } \\
\text { dominant/submissive and } \\
\text { affiliative/ } \\
\text { unaffiliative features e.g. I am } \\
\text { a confident person. }\end{array}$ \\
\hline
\end{tabular}


setting

Circumstantiation

$$
\begin{gathered}
\text { nominal group, material } \\
\text { processes, affective } \\
\text { process, } \\
\text { e.g. A good travelling } \\
\text { companion as I love to } \\
\text { travel, } \\
\text { Italy \& Spain }
\end{gathered}
$$
Circumstance of setting, mean and accompaniment.
Location e.g. Eiffle tower;
Instruments or objects used e.g. a camera;
Other participants in image e.g. friends.

Therefore, in a personal ad, the identity or the author (whether of linguistic or visual realisations) is verbally and visually constructed by means of participant depiction i.e. the advertiser's image or verbal description, the actions e.g. I love jungle trekking, the setting e.g. infront of the Eiffel tower, the means e.g. using a fishing rod to fish and the accompaniment e.g. posing with friends.

\subsection{The Data}

The personal advertisements were selected from a dating website called my.match.com. The website is an international site and its free membership allows users to place a personal advertisement on their system at no cost. my.match.com was selected as a source for personal ads for two reasons. First, it provides free (but limited) access to its users and secondly, the site claims to have 8 million members worldwide and to be visited by over 300,000 people a month. Individual profiles are available online, and are free to public view. The terms and conditions of the site state that personal information posted on the site is considered non-confidential and non-proprietary and they cannot be used in connection with any commercial activities.

The personal ads were accordingly selected based on two criteria:

1) Multimodality. As this is a multimodal study of both verbiage and imaged body language, the personal ad must contain both free-response description and personal image/s of the advertiser.

2) Marital status. The profiles selected are of men and women who identify themselves as single, separated, divorced or widow/widower.

\section{Results and Discussion}

\subsection{Personal ad Identity as a Multimodal Performance}

This section considers the construction of identities through the interplay of visual and verbal resources, focusing on two specific personal ad profiles of silkysultry 99 and excalibur9. Images and corresponding verbiage are selected from these two personal ads. Examples are taken verbatim from the advertisers' written description, and so instances of Malaysian English could often be found in the examples. Common errors that have become regular features of Malaysian English are the frequent omission of essential parts of clauses such as auxiliary verbs $b e$ and the suffix $-s$ (Ting et al., 2010). Despite these inaccuracies, identity description tend to be unaffected by these grammatical errors.

\subsection{Silkysultry99 as the Slim, Attractive and Empowered Woman}

Silkysultry 99 creates the personification of an empowered woman who takes pride in her looks via physical attribution, and her independence via leisure and occupational activities. She is represented mostly in terms of identification (i.e. who she is and what she looks like), followed by functionalization (i.e. what she does) through her leisure activities and the places she visited, and to a lesser extent through her occupation.

Focusing first on her personal identity, she verbally describes herself as follows:

I will used a few words to sum me up... sexy, wild, spontaneous, humorous, career minded, aggressive, confidence, living life to the fullest \& others... I'm 5'7", short hair, slim \& fair.

My dress sense... fashionable for the right occassion...but not a fashion slave. Because of my slim figure, I looks good in all clothes :)!

A chain of adjectives forming a succession of nominal groups constructs her identity with specific reference to her behavioural and physical traits - sexy, wild, spontaneous, humorous, aggressive, living life to the fullest. However, only one trait from this chain is visually co-articulated, sexy, as it is a form of physical appreciation that can be represented through a cluster of non-verbal features such as body parts and specific types of clothing items. This can be observed in the following two images in Figure 1.

Her exposed midriff and upper thighs construe the notion of sexy, made possible by specific clothing items (i.e. her cropped top and a mini skirt). Physically, her slim figure is verbally realized by the adjective slim that is mentioned twice in her text and visually represented in all her images through her physiologically slim boned 
features and small shoulders (Staffieri 1972). Her short hair is verbally described and visually displayed in all of her images. She is not a fashion slave, by virtue of a negated nominal group and accordingly, her style of dressing is consistent across the images (i.e. casual and body hugging style consisting of denim, simple tops, a jacket and a dress).

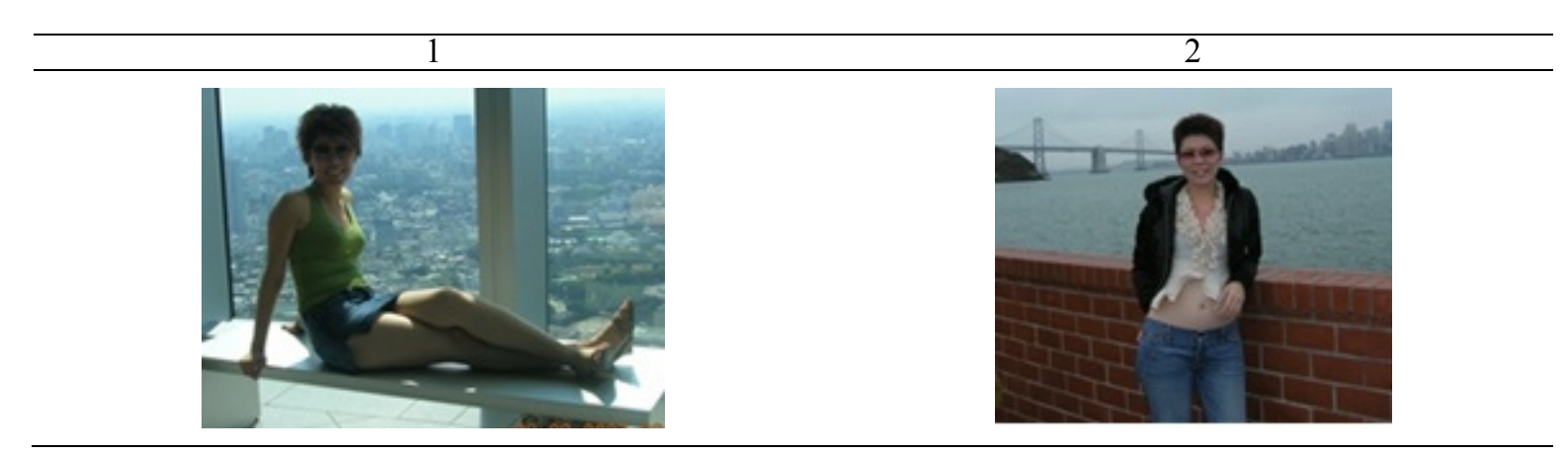

Figure 1. Visual representations of sexy

There is a complementary division of semiotic labour; both visual and verbal representation are converging to construe some aspects of her personal identity (i.e. her body type and her sexiness). The images commit corresponding meanings as the verbiage; together these verbal and visual resources converge to construe a slim and attractive feminine identity. Her choices of resources in image and verbiage with respect to the construction of the slim and attractive woman is summarised in Table 2 below.

Table 2. Verbal and visual resources for construing the slim and attractive woman

\begin{tabular}{|c|c|c|c|}
\hline $\begin{array}{l}\text { Feminine } \\
\text { identity }\end{array}$ & $\begin{array}{c}\text { identity categorization } \\
\text { type }\end{array}$ & verbal realisations & visual realisations \\
\hline $\begin{array}{l}\text { a slim and } \\
\text { attractive } \\
\text { woman }\end{array}$ & Identification: physical traits & $\begin{array}{l}\text { nominal groups, } \\
\text { attributive relational clauses: } \\
\text { sexy... } \\
\text { I'm 5'7", short hair, slim \& fair, } \\
\text { My dress sense (is) fashionable for the } \\
\text { right occassion... } \\
\text { But not a fashion slave, Because of my } \\
\text { slim figure, I looks good in all clothes :)! }\end{array}$ & $\begin{array}{l}\text { participant as Carrier with } \\
\text { Possessive Attributes: } \\
\text { depicted qualities } \\
\text { attributes: } \\
\text { ectomorph body type, hair } \\
\text { type, skin tone. } \\
\text { outfits: } \\
\text { a dress, midriff baring top, } \\
\text { fitted tops and slim pants. }\end{array}$ \\
\hline
\end{tabular}

In addition to looking sexy and slim, she has also verbally constructed her identity as an empowered woman - as the wild, spontaneous, humorous, career minded, aggressive, confidence, living life to the fullest type. While most traits are verbally inscribed, her confidence is visually enacted through a cluster of body language features in images three and four below. Confidence is enacted through her direct gaze, up-curved mouth shape, parted lips, open arm orientation and frontal body angle. Both verbal and visual resources converge to commit complementary meanings with respect to this personality trait. These multimodal co-articulations of confidence have the effect of intensifying personal description.

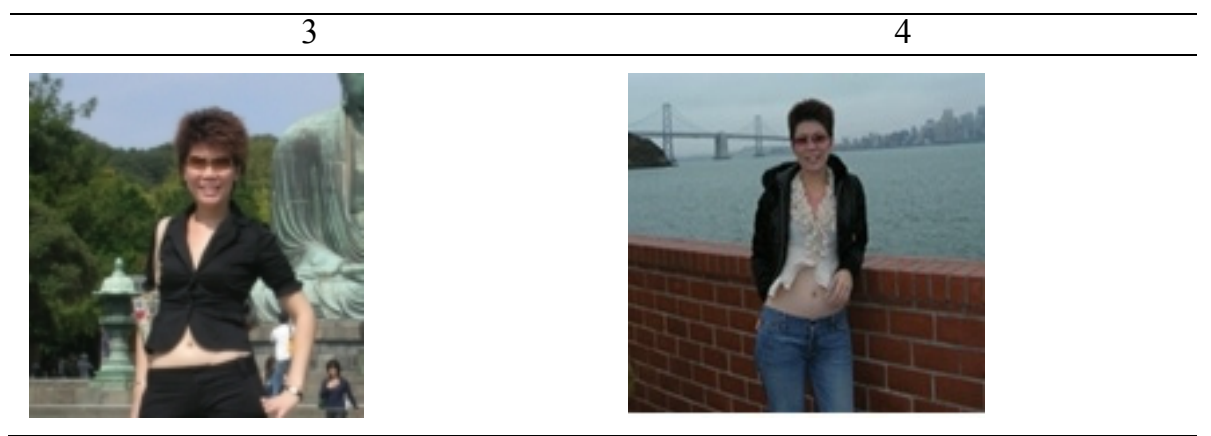

Figure 2. Visual representations of confidence 
Her reference to international travel suggests occupational stability and solvency. Leisure roles and travelling activities are realized in three ways, through nominal groups e.g. a good travelling companion, material processes e.g. travelling and an affective clause e.g. I love to travel. Silkysultry 99 appears focused on representing herself as an avid traveller; the convergence of visual and verbal realisations amplifies her identity performance and substantiates her lifestyle. Visually, her social identity as an avid traveller unfolds as a succession of images that locate her in several different settings (i.e. a Buddhist statue, a highland, and what looks like the Golden Gate Bridge in San Francisco) (see images five to seven in Figure 3).

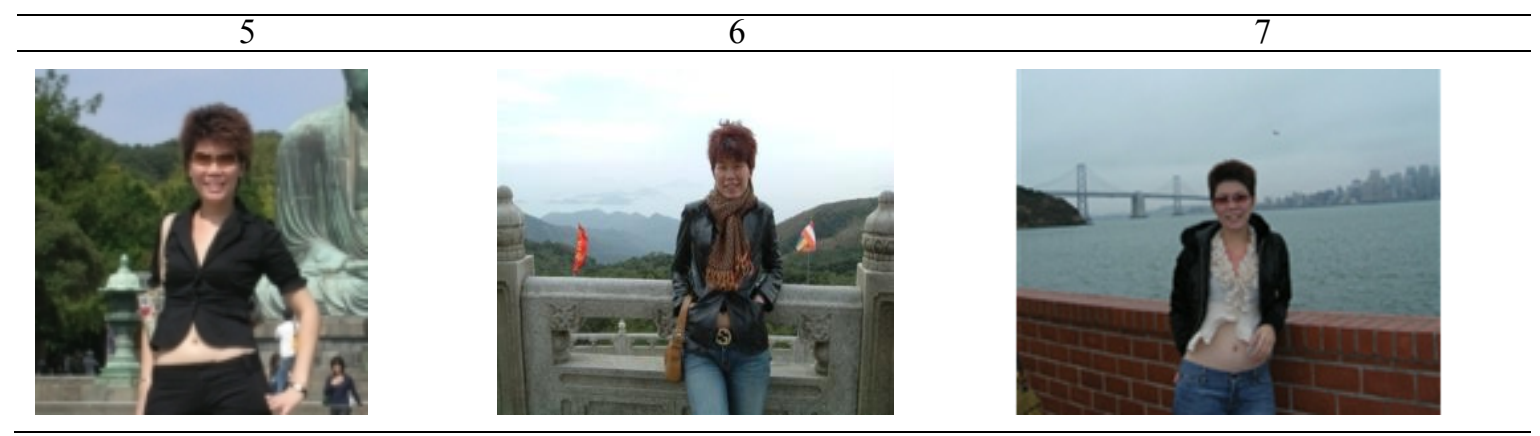

Figure 3. Visual circumstances of setting

Accordingly, the images commit a greater amount of meaning than the verbiage via the different circumstantial settings. The choices of converging verbal and visual resources in the construction of the empowered woman and avid traveller is summarised in Table 3 .

Table 3. Verbal and visual resources for representing silkysultry 99 as an empowered woman and an avid traveler

\begin{tabular}{|c|c|c|c|}
\hline $\begin{array}{l}\text { Feminine } \\
\text { identity }\end{array}$ & $\begin{array}{c}\text { Identity categorization } \\
\text { type }\end{array}$ & verbal realisations & visual realisations \\
\hline $\begin{array}{l}\text { The } \\
\text { empowered } \\
\text { woman }\end{array}$ & $\begin{array}{l}\text { Identification: } \\
\text { personality } \\
\text { traits }\end{array}$ & $\begin{array}{l}\text { nominal group: } \\
\text { confidence }\end{array}$ & $\begin{array}{l}\text { dominant-affiliative body } \\
\text { language features: } \\
\text { open arm orientation, } \\
\text { standing and leaning forward, } \\
\text { frontal angle, up-curved } \\
\text { mouth, parted lips } \\
\text { circumstances of setting: }\end{array}$ \\
\hline $\begin{array}{l}\text { The avid } \\
\text { traveller }\end{array}$ & $\begin{array}{l}\text { Functionalisation: } \\
\text { leisure role } \\
\text { activities }\end{array}$ & $\begin{array}{l}\text { nominal group, material processes, } \\
\text { affective process, } \\
\text { clause } \\
\text { A good travelling companion as I love } \\
\text { to travel } \\
\text { Travelling } \\
\text { Italy \& Spain. }\end{array}$ & $\begin{array}{l}\text { a Buddhist statue, the } \\
\text { highlands, and the Golden } \\
\text { Gate Bridge }\end{array}$ \\
\hline
\end{tabular}

To summarize, verbal and visual resources construing the slim and attractive, the empowered and the avid traveler have been identified. The slim \& the attractive and the avid traveller are both verbally and visually realised through a personal identification and leisure functionalisation, while the empowered emerged only through verbal realizations of occupational activities and role.

The next section looks at the verbal and visual representations of excalibur9.

\subsection{Excalibur 9 as the Sensitive New Age, the Successful Man and the Avid Traveller}

Excalibur9's self-representation realizes several identity types - the sensitive man, the avid traveler and the successful man with a sense of humour. Excalibur9's identity is predominantly constructed by means of functionalisation through leisure activities, and to a lesser extent, identification through inscriptions of personal traits. He uses humour to suggest wittiness and tenders individual and domestic activities that facilitate bonding between him and his readers. Focusing first on his identification as a man with a sense of humour, he starts with a succession of I-statements to characterize this persona:

I never give-in to anything, except Temptation. Well, I'm a fun-loving guy, who has a very positive outlook towards life and what it has to offer. I enjoy having nice conversations over coffee, hanging out just relaxing. People also know me as kelvingoh9 at the panasmail. Basically I'm a pilot looking for a co-pilot. 
Excalibur 9 uses descriptions that allude to his personality. I never give-in to anything invokes a positive trait of determination. The prepositional phrase except Temptation however creates a humorous effect, construing another aspect of his personality - sense of humour. He wittily plays up the marketing nature of personal ad by commodifying himself as Limited edition: not available on e-bay. In addition to being funny, I'm a fun-loving guy construes his positive temperament. Studies in gender attraction revealed that sense of humour is a highly desirable characteristic to both sexes (e.g. Sprecher \& Regan, 2002) and can be deployed as a strategy for initiating relationship (Li et al. 2009); accordingly, a man or a woman with a sense of humour could be said to possess a quality that is sought in the single market.

Visually, his body language in his primary image in Figure 4 depicts him in a humorous manner. His up-curved mouth, averted gaze, hand gesture and head prop, appear to be an embodiment of his fun-loving and funny self. His personal attributes are instantiated verbally through nominal groups and attributive clauses, and non-verbally through affiliative features and circumstance of accompaniment i.e. the antler headband. In terms of body language, he uses facial expression and arm orientation features to enact his sense of humour. On the whole, the juxtaposition of his verbal and visual resources converges to construe a fun-loving and humorous man.

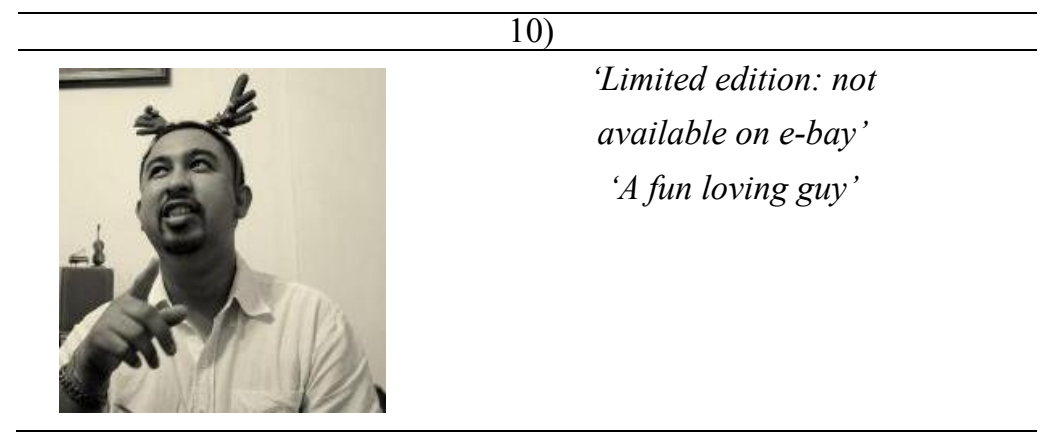

Figure 4. excalibur9 as a fun-loving and humorous man

There are instances of educational possessions (identification) and occupational roles (functionalisation) in excalibur9's personal ad, realized by material and intensive relational clauses and nominal groups: I graduated from MMU with a degree in Information Systems Engineering, and now I'm a Land Logistics Consultant. The verbs and the nominal groups functionalise him as a graduate, sub-classify his field of expertise and specify his occupational role. Excalibur9 also tend to inscribe positive affect towards his job as well as invoke positive reaction towards occupational activities. These processes are displayed in his profile through I love my job as I get to meet lots of interesting people from the corporate sector, lets me travel and learn new things. Overall, identification by means of ability and affect, and functionalisation by means of occupational role and activities verbally converge to construe a successful man.

Similar to silkysultry99, excalibur9's occupational role and activities are not visually represented in any of his images. The choices of resources in image and verbiage commitment with respect to excalibur9's occupational role and activities is summarised in Table 4.

Table 4. Verbal and visual representations of excalibur9 as a successful man with a sense of humour.

\begin{tabular}{|c|c|c|c|}
\hline $\begin{array}{l}\text { Masculine } \\
\text { Identity }\end{array}$ & $\begin{array}{c}\text { Identity categorization } \\
\text { type }\end{array}$ & verbal realisations & visual realisations \\
\hline $\begin{array}{l}\text { a successful } \\
\text { man }\end{array}$ & $\begin{array}{l}\text { Identification: } \\
\text { educational possession, }\end{array}$ & $\begin{array}{l}\text { nominal group, material processes, } \\
\text { relational process, affective process. }\end{array}$ & none \\
\hline & $\begin{array}{l}\text { Functionalisation: } \\
\text { occupational role and } \\
\text { activities }\end{array}$ & $\begin{array}{l}\text { I graduated from MMU with a degree in } \\
\text { Information Systems Engineering, and now } \\
\text { I'm a Land Logistics Consultant. } \\
\text { I love my job as I get to meet lots of } \\
\text { interesting people from the corporate } \\
\text { sector, lets me travel and learn new things. }\end{array}$ & \\
\hline $\begin{array}{l}\text { with a sense } \\
\text { of humour }\end{array}$ & $\begin{array}{l}\text { Identification: } \\
\text { behavioural traits. }\end{array}$ & $\begin{array}{l}\text { nominal group, material processes, } \\
\text { relational process. } \\
\text { Limited edition: } \text { not available on e-bay } \\
\text { I never give-in to anything, except } \\
\text { Temptation. } \\
\text { Well, I'm a fun-loving guy. }\end{array}$ & $\begin{array}{l}\text { Dominant/affiliative } \\
\text { pose features : } \\
\text { up-curved mouth } \\
\text { shape, parted lips, } \\
\text { open arm orientation, } \\
\text { frontal angle. }\end{array}$ \\
\hline
\end{tabular}


Excalibur9's love for travelling is verbally and visually instantiated in his ad. Circumstances of setting (e.g. The Twelve Apostles in Victoria- Image 14), the sea/beaches in images 11-14) converges with affective clauses (e.g. I love traveling, I love going for trips over the weekend to new places) and nominal groups (e.g. beaches, nice romantic gateways) to construe leisure functionalisation.

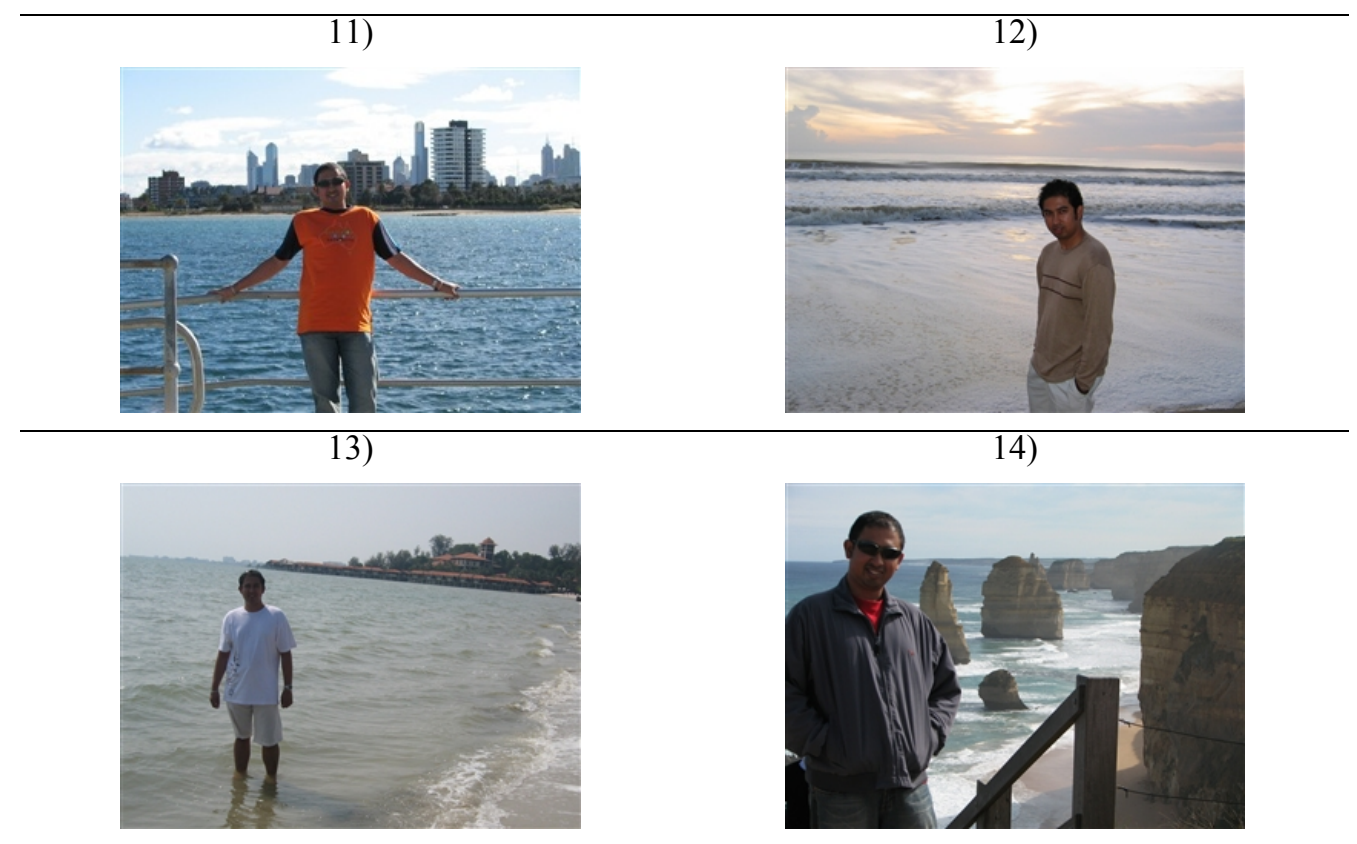

Figure 5. Visual realizations of the avid traveler

The noun beaches is repeatedly displayed in his images. While the verbiage commits only a single instance of his favourite hot spot, the representation of the beach is much more fully represented in the images in Figure 1.6 of different locations at different time of day. His visual text thus is richer than his verbal one in terms of the meanings committed and the space they occupy on his profile page. On the whole, verbal and visual resources in excalibur9's ad converge and build a holistic picture of an avid traveller. The choices of resources in image and verbiage with respect to leisure functionalisation is summarised in Table 5.

Table 5. Verbal and visual resources in representing excalibur 9 as an avid traveller.

\begin{tabular}{|c|c|c|c|}
\hline $\begin{array}{l}\text { Masculine } \\
\text { Identity }\end{array}$ & $\begin{array}{c}\text { identity categorization } \\
\text { type }\end{array}$ & verbal realisations & visual realisations \\
\hline $\begin{array}{l}\text { The avid } \\
\text { traveller }\end{array}$ & $\begin{array}{l}\text { functionalisation: } \\
\text { leisure role and activities }\end{array}$ & $\begin{array}{l}\text { nominal group, affective processes, material } \\
\text { processes. } \\
\text { I love traveling. } \\
\text { Taking my car out and going for long drives } \\
\text { not knowing where the road will take you. } \\
\text { I love going for trips over the weekend to new } \\
\text { places around and discovering good food, nice } \\
\text { romantic gateways. } \\
\text { Places where I can just unwind and relax. } \\
\text { Islands, beaches... }\end{array}$ & $\begin{array}{l}\text { circumstances of } \\
\text { settings: } \\
\text { the } 12 \text { apostles, the sea } \\
\text { \&beaches }\end{array}$ \\
\hline
\end{tabular}

Excalibur9's self-commodifying verbiage is subtle, unlike the typical personal advert. Absent is the chain of nominal groups that normally construes 'a set of fairly stable prototypes of desirability' (e.g. Bruthiaux 1994). Instead, his behavioural traits and activities are represented through a description of his desired other.

Some1 to share the laughter and sometimes share the tears. Some1 to share the early morning caffeine boost, or the late night ice cream craves. Somel to share the weekend gateways, or the weekday movie breaks. Somel to share the long drives over the weekend, or the short walks in the park. Somel to share the exciting action movies, or the romantic comedy laughs and tears. Somel to share the joy in buying new clothes, or the arguments of what colour of bedsheet to buy. Somel to cook for, or somel to clean up the dishes with. Somel to share the little things in live that makes the bigger things seem like life as it is, is filled with beautiful things, if only you know where to look. 
In the above extract, eight identical nominal group structures $($ Somel...) are post-modified by eight parallel non-finite structures (to share...) consisting of nominal groups, construing functionalization through leisure activities (e.g. the early morning caffeine boost, the weekday movie breaks and buying new clothes) and identification through positive and negative surges of emotion (e.g. the laughter and the tears). He has created a series of representation that not only instantiate his desired other but also his identity as a sensitive new age man. Domestic activities such as cooking, cleaning up dishes, and buying bedsheets and the act of sharing these with his potential other construe features of this sensitive man (McMahon, 1998). Doing activities traditionally associated with feminine persona can be read as his strategy for affiliating with women. However, these activities are only partially represented in his advert. This means that they are verbally represented but not visually realized, although the location in images 11-14 may allude to his weekend getaways. Table 6 is a summary of resources from verbal and visual systems deployed in construing the sensitive new age guy.

Table 6. Verbal and visual resources and the degree of commitment in representing excalibur 9 as the sensitive new age guy

\begin{tabular}{|c|c|c|c|}
\hline $\begin{array}{c}\text { Masculine } \\
\text { identity }\end{array}$ & $\begin{array}{c}\text { identity categorization } \\
\text { type }\end{array}$ & verbal realisations & visual realisations \\
\hline $\begin{array}{l}\text { the sensitive } \\
\text { new age guy }\end{array}$ & $\begin{array}{l}\text { identification: } \\
\text { behavioural traits. } \\
\text { Functionalisation: } \\
\text { leisure activities }\end{array}$ & $\begin{array}{l}\text { nominal group, material processes. } \\
\text { the laughter and the tears } \\
\text { the long drives over the weekend, } \\
\text { the short walks in the park. } \\
\text { the exciting action movies, } \\
\text { the romantic comedy laughs and tears. } \\
\text { the joy in buying new clothes, } \\
\text { the arguments of what colour of bedsheet to } \\
\text { buy. } \\
\text { to cook for, } \\
\text { to clean up the dishes with. }\end{array}$ & none \\
\hline
\end{tabular}

The above analysis has demonstrated how identities are instantiated from both verbal and visual systems. Verbal and visual resources converge in identity performances, construing the slim and attractive woman and the funny but sensitive guy, both aimed at invoking interest from potential partners. Identities emerged through the use of nominal groups and processes and the categorizations associated with these resources. Images that are displayed on the profile pages of the advertisers contain features that correspond to the tendered traits in the verbal description - i.e. that there are displays of female attractiveness, sense of humour and leisure activities, all contributing towards a holistic performance of online identities.

\section{Conclusion}

Discursive performance refers not only to the language that we use, but also other means of expressing identity; images are one such means for performing identity in personal ads. Personal ad identities as multimodal representations are conceptualized as choices from several semiotic resources i.e. language, image and static body language, integrating across linguistic and visual modes to construct meanings in context. The question of how these meaning choices combine across two modalities, and how they complement one another in identity construal was dealt with using the approach proposed by Painter and Martin (2010). It has been the intention of this paper to make a contribution to the area of multimodality by offering a new angle on identity representation that is informed by the tools afforded by social semiotics and systemic functional linguistics. I-statement, nominal group and visual grammar are only some of the tools afforded by the theories for analyzing identity representation. It is suggested that this theory and its array of tools be applied to analysis of identity performances in any multimodal texts as they are effective in making explicit both linguistic and paralinguistic options in identity construal in a multimodal text.

\section{References}

Bahiyah, A. H., \& Kesumawati, A. B. (2011). Articulating male and female adolescent identities via the language of personal advertisements: A Malaysian perspective. In A, Duszak, \& U. Okulska (Eds.), Language, Culture and the Dynamics of Age (pp. 191-220). Mouton Gruyter. Berlin/New York.

Baker, P. (2003). No effeminates please: A corpus-based analysis of masculinity via personal adverts in Gay News/Times 1973-2000. In B. Benwell (Ed.), Masculinity and men's lifestyle magazines. Blackwell. Oxford. http://dx.doi.org/10.3149/jms.0803.309

Bartholome, A., Richard, T., \& Alex, B. (2000). "I Want a Man”: Patterns of Attraction in All-Male Personal Ads. 
Journal of Men's Studies, 8(3), 309-321.

Benwell, B., \& Stokoe, E. (2006). Discourse and identity. Edinburgh: Edinburgh University Press.

Bolig, R., Stein, P. J., \& McKenry, P. C. (1984). The Self-Advertisement Approach to Dating: Male-Female Differences. Family Relations, 33, 587-592. http://dx.doi.org/10.2307/583839

Bruthiaux, P. (1994). Functional variation in the language of classified ads. Perspectives: Working Papers of the Department of English, City Polytechnic of Hong Kong, 6(2), 21-40.

Butler, J. (1996). Gender as Performance. In P. Osborne (Ed.), A Critical Sense: Interviews with Intellectuals (pp. 108-125). London. Routledge.

Cameron, C., Oskamp, S., \& Sparks, W. (1977). Courtship American style: Newspaper ads. The Family Coordinator, 26, 27-30. http://dx.doi.org/10.2307/581857

Coupland, J. (1996). Dating advertisements: discourses of the commodified self. Discourse and Society, 7(2). 187-207. http://dx.doi.org/10.1177/0957926596007002003

Ellison, N., R. Heino, R., \& Gibbs, J. (2006). Managing Impressions Online: Self-Presentation Processes in the Online Dating Environment. Journal of Computer-Mediated Communication, 11(2), article 2. http://dx.doi.org/10.1111/j.1083-6101.2006.00020.x

Fiore, A., \& Donath, J. (2002). Online Personals: An Overview. Retrieved from http://smg.media.mit.edu/ papers/atf/chi2004_personals_short.pdf

Gama e Silva, B. (2007). The Object of Virtual Desire: seducing on the Internet. Retrieved August 3, 2010, from http://www.unigranrio.br.

Gibbs, J. L., Ellison, N. B., \& Heino, R. D. (2006). Self-presentation in online personals: The role of anticipated future interaction, self-disclosure, and perceived success in Internet dating. Communication Research, 33(2), 1-26. http://dx.doi.org/10.1177/0093650205285368

Hogben, S., \& Coupland, J. (2000). Egg seeks sperm. End of story?: Articulating gay parenting in small ads for reproductive partners. Discourse and Society, 11(4). 459-486. http://dx.doi.org/10.1177/095792650001 1004002

Jones, R. (2000). Potato Seeking Rice: Language, Culture and Identity in Gay Personal Ads in Hong Kong. International Journal of the Sociology of Language, 143, 33-61. http://dx.doi.org/10.1515/ijs1.2000.143.33

Jones, R. (2009). Technology and Sites of Display. In C. Jewitt (Ed.). The Routledge Handbook of Multimodal Analysis (pp. 114-126). Oxon: Routledge.

Kress, G., \& van Leeuwen, T. (2006). Reading images: The grammar of visual design (2nd ed.). London: Routledge.

Li, N. P., Griskevicius, V., Durante, K. M., Jonason, P. K., Pasisz, D. J., \& Aumer, K. (2009). An evolutionary perspective on humor: sexual selection or interest indication? Personality and Social Psychology Bulletin, 35(7), 923. http://dx.doi.org/10.1177/0146167209334786

Marley, C. (2000). Beyond the usual: The modification of gender in a British dating ads column. Text-Interdisciplinary Journal for the Study of Discourse, 20(3), 271-306. http://dx.doi.org/10.1515/text.1. 2000.20.3.271

McMahon, A. (1998). Blokus domesticus: the sensitive new age guy in Australia. Journal of Australian Studies, 6, 147. http://dx.doi.org/10.1080/14443059809387369

Mehrabian, A. (1971). Silent Messages (1st ed.). Wadsworth. Belmont.

Mehrabian, A. (1981). Silent Messages: Implicit Communication of Emotions and Attitudes (2nd ed.). Wadsworth. Belmont.

Miller, E., Smith, J., \& Trembath, D. (2000). The 'skinny' on body size requests in personal ads. Sex Roles, 43, 129-141. http://dx.doi.org/10.1023/A:1007047914166

Painter, C., \& Martin, J. (2013). Intermodal complementarity: Modelling affordances across image and verbiage in children's picture books. Ilha do Desterro: A Journal of English Language, Literatures in English and Cultural Studies.

Shalom, C. (1997). That great supermarket of desire: attributes of the desired other in personal advertisements. In K. Harvey, \& C. Shalom (Eds.), Language and Desire: encoding sex, romance and intimacy. London: 
Routledge

Sprecher, S., \& Regan, P. C. (2002). Liking some things (in some people) more than others: Partner preferences in romantic relationships and friendships. Journal of Social and Personal Relationships, 19, 436-481. http://dx.doi.org/10.1177/0265407502019004048

Staffieri, J. R. (1972). Body Build and Behavioral Expectancies in Young Females. Developmental Psychology, 6, 125-27. http://dx.doi.org/10.1037/h0032211

Tajfel, H., \& Turner, J. T. (1986). The social identity theory of intergroup behavior. In S. Worchel, \& W. G. Austin (Eds.), Psychology of Intergroup Relations (pp. 7-24) Chicago: Nelson.

Ting, S.-H., Mahadhir, M., \& Chang, Si.-L. (2010). Grammatical errors in spoken English of university students in oral communication course. GEMA Online TM Journal of Language Studies, 10(1), 53-70.

Van Leeuwen, T. (2008). Discourse and practice: New tools for critical discourse analysis. Oxford University Press, USA. http://dx.doi.org/10.1093/acprof:oso/9780195323306.001.0001

Walther, J. B., \& Parks, M. R. (2002). Cues filtered out, cues filtered in: Computer-mediated communication and relationships. In M. L. Knapp, \& J. A. Daly (Eds.), Handbook of Interpersonal Communication (3rd ed., pp. 529-563). Thousand Oaks, CA: Sage.

Woodward, K. (Ed.). (2004). Questions of Identity. London: Routledge.

\section{Copyrights}

Copyright for this article is retained by the author(s), with first publication rights granted to the journal.

This is an open-access article distributed under the terms and conditions of the Creative Commons Attribution license (http://creativecommons.org/licenses/by/3.0/). 